\title{
Development in the learning factory: training human capital
}

\author{
Harry Barton \\ Cardiff Business School, Cardiff, Wales \\ Rick Delbridge \\ Cardiff Business School, Cardiff, Wales
}

\section{Keywords}

Human resource management, Manufacturing industry,

Innovation, Training

\section{Abstract}

Examines innovation, labour and human resource management in contemporary manufacturing. Case study data are presented from automotive plants in the USA and the UK. Reports on the human resource practices in use and considers the relationship with the plants' manufacturing and innovation activities. In particular, focuses on current developments in the roles of employees and their training and development implications.

\section{Introduction}

It is conventional wisdom that the factories of the future will be sites of continuous improvement, innovation and knowledge creation (Leonard-Barton, 1992; Cooke and Morgan, 1998), with the focus being on the development of a set of strategies and organizational forms based on high skills, organizational flexibility and trust, often termed "high-performance work practices" (OECD, 1998a). This view has been formulated following research into developments in large manufacturing organizations (Womack et al., 1990; MacDuffie, 1995) and in particular Japanese manufacturers (Fruin, 1992; Kenney and Florida, 1993), where human resources and work practices are often considered central to the success of the Japanese automotive producers (MacDuffie and Pil, 1999). Such views raise fundamental questions regarding the role of labour in such manufacturing systems and, as a direct consequence, there has been increasing interest in the human resource management (HRM) of these organizations (Arthur, 1992; Osterman, 1994; Pil and MacDuffie, 1996; Whitfield and Poole, 1997).

Such developments, however, are not unique to Japanese manufacturers. There has been a considerable body of research conducted within indigenous US organizations (Kochan et al., 1986: Lawler, 1992; MacDuffie and Pil, 1999) that reports an association between firm-level measures of HRM systems and organizational performance (Delaney and Huselid, 1996). In an attempt to build upon this, we present case evidence from automotive component plants in the USA and UK. We report on the human resource practices in use and consider their relationship with the plants' manufacturing and innovation activities. In particular we focus on current developments in the roles of employees and the training and development implications of them.

\section{Innovation, labour and HRM in contemporary manufacturing}

Cooke and Morgan (1998) identify the "semipermanent process of organizational innovation" as a central feature of contemporary manufacturing. Under such circumstances firms and organisations achieve their objectives by using the "innovative abilities of individuals more effectively" (OECD, 1998b, p. 273). Florida et al. (1998, p. 199) further argue that:

... the defining characteristic of the new work regimes is their ability to promote knowledge mobilisation and organizational learning. The model consists of three dimensions teamwork, worker involvement, and training - each of which comprises a set of practices that contribute to organizational learning.

This has important implications for all aspects of business organization, including corporate governance, formal research and development activities, supply chain management and the formation of collaborative networks (Cooke and Morgan, 1998). Alongside these, there has been considerable interest in the implications for the factories themselves. Delbridge et al.'s (1998, p. 227) outline of the key attributes of the manufacturing facilities within these organizations suggests they are:

... host to continuous improvement activities that are driven by internal sources of information such as the tacit knowledge of shop-floor workers, the "contextual" knowledge of technicians, and the "formal" knowledge of professionals and craft workers. 
Harry Barton and

Rick Delbridge

Development in the learning

factory: training human

capital

Journal of European Industrial

Training

25/9 [2001] 465-472
Thus the emphasis on innovation in manufacturing has called into question the traditional division of labour under Tayloristic approaches to the management of the labour process. Kenney and Florida (1993), for example, argue that the need for workers that think as well as do requires a "post-Fordist" management system, which they call "innovation-mediated production". The central feature here is the reintegration of production and innovation and of intellectual and physical labour. Snell and Dean (1992, p. 472) review a number of research projects into such developments. They conclude:

... these findings represent a trend toward

"upskilling" employees into "knowledge workers", whose responsibilities do not include only physical work.

These authors claim that contemporary manufacturing requires a broadening of worker skill and the combination of these skills into cross-functional problem-solving groups. For example, Cooper's (1999) research indicates that the introduction of true cross-functional teams can dramatically improve the time to market of new products and impacts on the success of new product development.

Such developments have revitalised managerial interest in employee participation, particularly since a number of authors have sought to explicitly demonstrate a positive relationship between participation and organisational efficiency (Strauss in Heller et al., 1998). Strauss identifies problem-solving groups, total quality management and team working as examples of "direct participation". Further he notes that employees may not be willing to participate in such activities, indeed a number of studies have reported workers withdrawing "discretionary effort" as a form of resistance (Graham, 1995; Delbridge, 1998). For this reason, the supporting HRM practices have come under close scrutiny:

A major finding of many studies is that direct participation is unlikely to prosper or even to survive unless it is accompanied by other appropriate human-resource policies (Strauss in Heller et al., 1998, p. 195).

Previous research on new forms of work organization have tended to focus on individual practices such as the use of teams, job rotation, job classifications, and so forth. However, recent work suggests that such practices are most effective when used together as interrelated systems referred to variously as "transformed", "flexible", "high commitment" and "high performance" work systems (Florida et al., 1998). This view is supported by MacDuffie (1995), who argues for the integrated "bundling" of high commitment and high involvement HR practices and lean operations. He argues that it is the mutually reinforcing nature of these bundles of practices taken together which characterises high-performance workplaces. Such findings have fuelled the view that the workforce represents an asset and should be considered accordingly.

\section{Employee participation and human capital}

There are a number of alternative views on the apparent value of human capital theory to contemporary manufacturing organisations, with two primary perspectives emerging. They are:

... a universal perspective, implies a direct relationship between particular approaches to human resources and performance, and the contingency perspective posits that an organization's strategic posture either augments or diminishes the impact of HR practices on performance (Youndt et al., 1996, p. 837).

We argue within this paper that both perspectives are observable and may indeed be "complementary" (Youndt et al., 1996). Organizations exist within a state of flux, which potentially could enable them to evolve from one organizational form to another, the key factor being the ability of the organization to strategically adapt to different commercial conditions. Strategic considerations, however, are still underpinned by positive workplace practices. Strauss's (in Heller et al., 1998) discussion of the HR policies that may be important in promoting/sustaining direct participation concentrates upon compensation, status and symbols, job security and training (although he also mentions selective hiring and promotion from within as potentially important).

In summarising the current state of knowledge, Strauss (in Heller et al., 1998) indicates what may be expected of these HR practices if they are to be effective in their support of direct participation schemes. With regard to compensation he suggests that: ... policies should reward participative efforts, be viewed as fair, and not disrupt social cohesion. Successful direct participation plans have increasingly been accompanied by "pay for knowledge" ... and/ or some sort of financial participation, such as stock ownership, profit-sharing, or gainsharing based on group or organizational performance (Strauss, in Heller et al., 1999, p. 206)

In addition to financial rewards, Strauss notes the key significance of symbols and 
Harry Barton and

Rick Delbridge

Development in the learning

factory: training human

capital

Journal of European Industrial

Training

25/9 [2001] 465-472 status and he reflects that successful participation is often accompanied by a reduction in status differentials.

Alongside appropriate rewards, Strauss argues that direct participation is likely to work best when combined with prospects of future job security and long-term employment, "Worry over possible job loss normally inhibits co-operation" (Strauss, in Heller et al., 1998, p. 207). Finally he considers the importance of training and notes that: ... participation requires that employees have the "competence" to engage in it ... Work team members need training in breadth and depth - in breadth so that they can perform each others' jobs and in depth so that they resolve unforeseen problems as they occur without running to staff or management for assistance (Strauss, in Heller et al., 1998, p. 208).

To participate fully and effectively in problem-solving and continuous improvement activities, shopfloor workers will need not only technical, analytic and planning skills but also interpersonal training.

Snell and Dean (1992) assess the extent to which advanced manufacturing has been accompanied by developments in these organisations' HR approach. As they acknowledge:

... critics have charged that changes in manufacturing often are not accompanied by complementary changes in human resource management (Snell and Dean, 1992, pp. 467-8).

Specifically they draw upon "human capital theory", which recognises the skills, experience and knowledge that people have and the economic value of these to firms. In this sense individuals add value:

... directly by transforming the firm's product, but much less of it is tangible, consisting of solving problems, co-ordinating the work of departments, and exercising judgement in novel situations (Snell and Dean, 1992, p. 469).

This view recognises the broadening role of labour in the learning factory and regards HRM as investments in human capital. However, as Snell and Dean (1992, pp. 469-70) also recognise:

Employees are not valuable in the abstract, but rather as a function of the jobs they perform ... Thus, the value of human capital investments depends upon the demands placed on the employees.

For this reason our paper considers the integration of HRM with the business practices of a number of case study plants and also assesses management's attempts to encourage HR practices that support innovative activities. Specifically we consider how greater employee participation is encouraged through various problemsolving and continuous improvement activities.

\section{The research project}

This paper draws on data gathered from a total of 18 manufacturing plants operating in the US and UK automotive components industries, specifically facilities manufacturing seats, exhaust systems and disc brake calipers. The overall aim is to gather both quantitative and qualitative data in order to understand the approach to learning and improvement within each plant, the role of labour in this and to discern links between learning and organisational performance. In order to collect the data, each plant was visited by a pair of researchers on two separate occasions. Management were asked to complete a questionnaire which provided information on the plant's management practices and manufacturing performance. Structured interviews were conducted with representatives from different functional groups, including quality, manufacturing, engineering, HR, maintenance and supply chain management. In addition, interviews were conducted with shopfloor workers, team leaders and production supervisors, and team and problem-solving meetings were observed. The project is funded by the UK government's Engineering and Physical Sciences Research Council (grant GR/ L93591). In this paper we summarize developments and then we concentrate on three case plants, one each in seat assembly, brake and exhaust system manufacture.

\section{HRM within the case plants}

\section{Background}

Globally, the automotive industry continues to rationalize and streamline its operations in response to an increasingly competitive market. This has been apparent as we have conducted our research within first tier automotive component suppliers of seats, disc brake calipers and exhausts. In many of the plants that we have researched in the course of this project, there is a clear shift in emphasis, away from a bureaucratic and hierarchical organization to that in which centralized systems of decision making and control are devolved to line managers. Such managers are being increasingly judged on their ability to meet exacting corporate targets. 
Harry Barton and

Rick Delbridge

Development in the learning

factory: training human

capital

Journal of European Industrial

Training

25/9 [2001] 465-472
Across all the sites visited, managers (particularly plant managers) have been given enhanced responsibilities for financial and physical resources; they are also being held more accountable for achieving a high degree of efficiency in the use of those resources and are increasingly encouraged to focus on "value added" activities. Almost without exception these involve some element of cost reduction, which in the 1990s has, in the main, resulted from lean product design and the simplification of incremental innovations (Fujimoto, 1998). There are, however, some striking differences across the plants visited in the degree of autonomy enjoyed by individual plant managers. At one extreme, plant managers have had to report to their corporate headquarters on a daily basis, while others had a relatively informal, arm's length relationship.

In this section we review the implications for HRM that these developments in manufacturing have and consider whether the firms in the study display evidence of moves consistent with a "human capital" approach. This is important given that there is growing evidence to suggest that firm-level high-performance workplaces and work practices depend on "high skill" strategies that make better use of and continuously renew human capital (OECD, 1997, 1998a).

In one sense, under these circumstances, people account for a significant element of cost. However, consistent with the human capital view, there is an acceptance within a number of plants studied that in order for their organization to achieve improved performance and standards of quality, greater emphasis has to be placed on the training and development needs of their core employees, and in particular their shop-floor workers, front line managers and supervisors. This suggests that expenditure on their selection, training and motivation represents as much an investment as it does a cost. Therefore this would be consistent with the notion of the "learning factory": where the accent is on highly participative workplace practices. These involve crossfunctional teams of workers involved in both long-term and task-specific problem-solving activities, supported and encouraged by the development of "high skill" strategies.

Across the plants visited there would appear to be a growing understanding of the need to develop policies that focus on human resources and human capital accumulation for their long-term economic development and, ultimately, success. However there is a wide variation in the degree to which such policies have been implemented across the case plants studied. Some demonstrate a willingness and commitment to ongoing personal and professional development for their employees, whilst at the other end of the spectrum, training and development were still seen very much as a cost that had to borne; the management challenge being to minimise such expenditure.

\section{The role of line managers and supervisors}

To be consistent with the "learning factory" model, one would expect to find line managers operating with greater autonomy. This would then concur with the notion of "high trust" work practices, which are increasingly seen as having an important impact on firm productivity and performance (OECD, 1998a).

Our research identified that increasingly line managers were being held accountable for the quality and cost effectiveness of that part of the production process that they had responsibility for. However, it was not clear in many instances whether this apparent delegation of responsibility was matched with a corresponding delegation of authority in so far as freedom of action in the management of their staff. Managers were given responsibility to develop effective teams and, in some instances, were able to change work processes without having to go through complicated authorization procedures. The degree to which they were able to reward good performance and correct poor standards was less apparent.

Under the learning factory model, and in promoting organizational participation, front-line managers should be free to contribute. The difficulties and frustrations expressed by many managers who were interviewed, relate to this concept. A number reported concerns over limited managerial resources (characterized by very flat management structures) and constantly changing financial demands being imposed on them, either corporately or by their customers. The solution to this appears to be a trend in the direction of increased empowerment to shop floor employees, which is increasingly manifesting itself in the form of "team leaders" who have delegated responsibility for day-to-day operational management of a number of workers.

Although not as pronounced as has been the case in Japanese manufacturing plants for many years (Aoki, 1990; Koike, 1989), our research shows that in some plants the "team leader" has an influential role over performance evaluations and the settlement of complaints and grievances. As with the research conducted by MacDuffie and Pil (1999) into Japanese automotive transplants 
Harry Barton and

Rick Delbridge

Development in the learning

factory: training human

capital

Journal of European Industrial

Training

25/9 [2001] 465-472 in the USA, we have identified instances of greater worker participation in areas of recruitment, issues related to work and problem solving. This was recognised in earlier research (Womack et al., 1990; Lowe, 1993) where it was identified that with the advent of "lean production", distinct changes could be seen in terms of work organization. This is typified with a move away from the principles of mass production where:

... task conception is separated from execution, leaving knowledge, information, responsibility and authority for decision making primarily in the hands of specialist departments (Lowe, 1993, p. 740).

Under the principles of lean production there is less specialisation and a greater transfer of tasks and responsibilities to those workers at the point of production, and implicit with this to their front line managers and supervisors:

Thus, task conception and execution both occur at the point of production with knowledge, information and authority for decision taking necessarily focused much more at a line level than is the case for traditional mass producers (Lowe, 1993, p. 741).

In facilitating and leading this, front-line supervisory management faces new challenges, with a greater emphasis being placed on the development of those inter-personal skills that can encourage, develop and motivate workers to assume responsibilty for their own, or team-based, quality and productivity targets. Such challenges have implications for organisations in terms of training and this is explored in the next section.

\section{Training and development}

In line with the human capital perspective, raising the skills of the labour force is seen as important in contributing to the spread of "high-skill" work practices and thus enabling higher productivity growth. Too many companies assume that their employees will simply rise to the occasion when it comes to a new product launch (Cooper, 1999) or when a new initiative is introduced they will adapt to changes in their functional role. Without training it is unlikely that there will be a significant impact on enterprise performance (OECD, 1997; 1998b, p. 287). The success of an organization depends on the skills and actions of its people and a key determinant of this will be the way they are developed, including the training they receive. Although the plants we have researched provide similar levels of training to new employees, there is a variation to the degree and extent of training to employees, post-induction and probation. To an extent, the training provided can be quite haphazard, as the HR manager in a seat manufacturing plant explained:

We do have a training plan which states the required training for every position in the plant. We have somewhat of an idea, but we are not real formal about what we want to accomplish for that year.

Within this plant there was little evidence of any evaluation of the effectiveness of the training that did take place. In another example, this time from the HR manager of a disc brake caliper manufacturer, when asked about the nature of training undertaken, the response was:

We have a training budget that anybody and everybody uses. It's in HR, it's kind of strange, I am responsible for the training budget, I approve training requests, but they come from all over the organization and anybody can put anything into training under my budget and I would not necessarily see it.

Our evidence suggests therefore that in the main, post-induction opportunities for training may be available, however it is either up to the individual to seek it out or it occurs as a result of actions arising from a supervisor/line manager. This places additional emphasis on the front-line management role, but in the worst instances there is little evidence for training individuals in the basics of supervisory management following promotion. As one HR manager explained:

Do we have a formal training programme? When somebody says "OK hit them with the magic wand and now you're a supervisor?" No. We do some orientation with them, a little bit of what to expect and things like that.

MacDuffie and Pil (1999) identify such inadequacies in training in their research on Japanese and US automotive plants, with Japanese transplants providing significantly more training than their US owned counterparts for all employees - both newly hired and experienced workers. They also suggest, and this is borne out by our own observations, that there is some evidence to suggest that training at some plants is "viewed not just as a means to develop skills but as a socialization tool" (MacDuffie and Pil, 1999, p. 380).

There is evidence that there is a relationship with the problem-solving and HR approaches (see Table I). For example, if we take a random selection of three plants (one from each product area) from the 18 case plants there would appear to be significant differences between the seat plant and the other two plants in terms of recruitment, selection, training and job security. With the 
Harry Barton and

Rick Delbridge

Development in the learning

factory: training human

capital

Journal of European Industrial

Training

25/9 [2001] 465-472

$\overline{\text { Table I }}$

Some HR practices in the three case plants

\begin{tabular}{|c|c|c|c|}
\hline & Exhaust plant & Brake plant & Seat plant \\
\hline Number of operators & c.100 & c.200 & c. 350 \\
\hline \multicolumn{4}{|l|}{ Percentage of operators receiving } \\
\hline off-the-job training last year & 100 & 100 & 10 \\
\hline \multicolumn{4}{|l|}{ Average total length of operator } \\
\hline off-the-job training last year & 8 hours & 7 hours & 25 hours \\
\hline Applications per operator position & 10 & 3 & 10 \\
\hline Length of time assessing new recruits & 1.5 hours & 1.5 hours & 8 hours \\
\hline Operator reward scheme & $\begin{array}{l}\text { Hourly based on job } \\
\text { grade }\end{array}$ & $\begin{array}{l}\text { Hourly plus bonus } \\
\text { based on plant } \\
\text { performance } \\
\text { (average } 4 \text { percent) }\end{array}$ & $\begin{array}{l}\text { Hourly plus bonuses } \\
\text { for group and plant } \\
\text { performance } \\
\text { (average } 10 \text { percent) }\end{array}$ \\
\hline \multicolumn{4}{|l|}{ Percentage of employees on temporary } \\
\hline contracts of one year or less & 0 & 0 & 15 \\
\hline
\end{tabular}

seat plant spending up to five times as long in assessing the suitability for employment of new recruits and giving up to three times more off-the-job training to its shopfloor operators than the other two plants.

One explanation for this would appear to concur with earlier research undertaken by MacDuffie and Pil (1999) and is related to the corporate philosophy of the seat plant observed. Managers acknowledge that the recruitment process is standardised and as a result the workers hired are relatively homogeneous with respect to the plant's manufacturing philosophy and their attitude towards their work. The relatively high amount of "training is designed to create a stronger and more consistent culture" (MacDuffie and Pil, 1999, p. 380).

Conversely, however, whereas the brake and exhaust plants provide training to all of their operators, which would be in line with the human capital model, the seat plant provides it to only ten percent of operators and has significantly more of its employees on temporary contracts. Likewise the seat plant does not appear to encourage widespread worker participation in the form of suggestion activities, with only five per cent of operators involved in producing any suggestions, which when averaged across the plant equates to less than one suggestion per operator per year (Table II). Thus across the three plants we can identify both similarities and significant differences in both HR practices and the extent to which operators participate in problem-solving and continuous improvement activities. Further analysis will be conducted in the future to examine whether there is any relationship between these observations and the relative success, in terms of business performance, of participating plants.

\section{Concluding remarks}

The data presented here provide significant evidence of important developments in how the role of labour in manufacturing is changing. In particular, there is some support for the view that the need for greater innovation and change is leading to greater demands being placed upon front-line managers and shopfloor workers. Preliminary findings suggest that organizations are seeking to encourage increased participation amongst shopfloor employees and are looking to delegate traditionally managerial decisions to lower levels. This is creating a new work environment for many lower-level employees and is also enforcing changes on management functions.

As an example of this, we have looked at the nature and extent to which training was being used to increase the abilities of lowerlevel employees and first-line managers to adapt to their changing roles. There was some evidence to suggest that the traditional

\section{Table II}

Problem-solving and continuous improvement activities in three case plants

\begin{tabular}{lccc}
\hline & Exhaust plant & Brake plant & Seat plant \\
\hline Suggestion scheme? & No & Yes & Yes \\
Suggestions per operator per year & N/A & 13 & $<1$ \\
Routine problem-solving teams & Yes & Yes & Yes \\
Percentage of operators involved & 30 & 70 & 5 \\
\hline
\end{tabular}


Harry Barton and

Rick Delbridge

Development in the learning

factory: training human

capital

Journal of European Industrial

Training

25/9 [2001] 465-472 role of training within the manufacturing plants was being refocused to include more emphasis on enhancing and developing individuals' interpersonal skills, particularly in terms of front-line managers and supervisors, with an increasing focus being on team building and leadership skills. Difficulties however were identified by a number of HR managers who expressed the view that although they were now developing more far-ranging training strategies that involved such activities, "time" and suitable training facilities were often problematic. One consequence of this was that the availability and continuity of training courses was often affected and had an adverse effect on an employee's perception of the importance and necessity for such training.

In overviewing these developments there is a danger that we have exaggerated the similarity between plants. Therefore, in the final section, we have presented data that show the variation that is witnessed between the plants. These data suggest differing approaches to training and illustrate a distinction between plants that adopt administrative HR systems, with the emphasis remaining on policy and procedural training to those designed to enhance the level of human capital within the plant (Youndt et al., 1996, p. 846). Where observed, this human-capital-enhancing approach involved more comprehensive training programmes, with an emphasis on the development of greater technical and problem-solving skills.

Further, our initial work suggests that plants may look to an inclusive and participative approach that emphasizes the contribution of the vast majority of employees in continuous improvement activities. This clearly has implications for HRM, including rewards and training needs. On the other hand, one of the case plants has concentrated its efforts on incorporating the discretionary effort of what the production manager described as the "willing minority" who have voluntarily participated. This in turn has differing implications for the HR department.

\section{References}

Aoki, M. (1990), "Towards an economic model of the Japanese firm", Journal of Economic Literature, Vol. 28, pp. 1-27.

Arthur, J. (1992), “The link between business strategy and industrial relations systems in American minimills", Industrial and Labor Relations Review, Vol. 45 No. 3, pp. 488-506.

Cooke, P. and Morgan, K. (1998), The Associational Economy: Firms, Regions and Innovation, Oxford University Press, Oxford.
Cooper, R.G. (1999), "Success factors in product innovation”, Journal of Product Innovation Management, Vol. 16, pp. 115-33.

Delaney, J.T. and Huselid, M.A. (1996), “The impact of human resource management practices on perceptions of organizational performance", Academy of Management Journal, Vol. 39 No. 4, pp. 949-69.

Delbridge, R. (1998), Life on the Line in Contemporary Manufacturing, Oxford University Press, Oxford.

Delbridge, R., Kenney, M. and Lowe, J. (1998), “UK manufacturing in the twenty-first century learning factories and knowledge workers?", in Delbridge, R. and Lowe, J. (Eds), Manufacturing in Transition, Routledge, London.

Florida, R., Jenkins, D. and Smith, D.F. (1998), "The Japanese transplants in North America: production organization, location, and research and development", in Boyer, R., Charron, J.J., Jurgens, U. and Tolliday, S. (Eds), The Transfer and Hybridisation of Production Models in the International Automotive Industry, Oxford University Press, Oxford.

Fruin, M. (1992), The Japanese Enterprise System, Oxford University Press, Oxford.

Fujimoto, T. (1998), "A case of the capability evolution: Toyota and Japanese auto industry", La Lettre du Gerpisa, No. 119, January.

Graham, L. (1995), On the Line at Subaru-Isuzu, ILR Press, Ithaca, NY.

Heller, F., Pusic, E., Strauss, G. and Wilpert, B. (1998), Organizational Participation: Myth and Reality, Oxford University Press, Oxford.

Kenney, M. and Florida, R. (1993), Beyond Mass Production: The Japanese System and Its Transfer to the United States, Oxford University Press, New York, NY.

Kochan, T., Ketz, H. and Mckersie, R. (1986), The Transformation of American Industrial Relations, Basic Books, New York, NY.

Koike, K. (1989), Understanding Industrial Relations in Modern Japan (translated by Saso, M.), St Martin's Press, New York, NY.

Lawler, E.E. III (1992), The Ultimate Challenge, Jossey-Bass, San Fransisco, CA.

Leonard-Barton, D. (1992), "The factory as a learning laboratory”, Sloan Management Review, Fall, pp. 23-38.

Lowe, J. (1993), "Manufacturing reform and the changing role of the production supervisor: the case of the automobile industry", Journal of Management Studies, Vol. 30, 5 September.

MacDuffie, J.P. (1995), "Human resource bundles and manufacturing performance: organisational logic and flexible production systems in the world auto industry", Industrial and Labor Relations Review, Vol. 48 No. 2, pp. 199-221.

MacDuffie, J.P. and Pil, F.K. (1999), "What makes transplants thrive: managing the transplant of 'best practice' at Japanese auto plants in 
Harry Barton and

Rick Delbridge

Development in the learning

factory: training human

capital

Journal of European Industrial

Training

25/9 [2001] 465-472
North America”, Journal of World Business, Vol. 34 No. 4, pp. 372-91.

OECD (1997), Lifelong Learning to Maintain Employability, OCDE/GD(97) 162, OECD, Paris.

OECD (1998a), Technology, Productivity and Job Creation - Best Policy Practices, OECD, Paris.

OECD (1998b), Pathways and Participation in Vocational and Technical Education and Training, OECD, Paris.

Osterman, P. (1994), "How common is workplace transformation and who adopts it?",

Industrial and Labor Relations Review, Vol. 47 No. 2, pp. 173-88.

Pil, F. and MacDuffie, J.P. (1996), 'The adoption of high-involvement work practices”, Industrial Relations Review, Vol. 47 No. 2, pp. 173-88.
Snell, S. and Dean, J. (1992), "Integrated manufacturing and human resource management: a human capital perspective", Academy of Management Journal, Vol. 35 No. 3, pp. 467-504

Whitfield, K. and Poole, M. (1997), “Organizing employment for high performance: theories, evidence and policy”, Organization Studies, Vol. 18 No. 5, pp. 745-64.

Womack, J., Jones, D. and Roos, D. (1990), The Machine that Changed the World, Rawson Macmillan, New York, NY.

Youndt, M.A., Snell, S.A., Dean, J.W. Jr and Lepak, D.P. (1996), "Human resource management, manufacturing strategy, and firm performance", Academy of Management Journal, Vol. 39, pp. 836-66. 